\title{
Visual scale and Naturalness of Roadside Vegetation Landscape. An exploratory study at Pargua Highway, Puerto Montt - Chile
}

\author{
Carolina G. Ojeda* \\ Universidad Católica de la Santísima Concepción (UCSC), Alonso de Ribera 2850 - Concepción.
}

\begin{abstract}
Over the last few decades, the Chilean Government has constantly promoted the construction of private highways in order to increase the effectiveness in terms of transportation of goods and people all along the country. In this way, heavy road infrastructures, landscape fragmentation, loss of endangered animals' habitat, loss of visual quality, and a decrease of biodiversity patches have emerged. Despite this, some greenery native and introduced flora/fauna, natural elements, colors, lines, patterns, among others- can be partly seen in certain areas of Chilean highways. In particular, this paper focuses on the main route connecting Puerto Montt and Pargua cities in Los Lagos region.

The objectives of this qualitative research are threefold. Firstly, to measure main Landscape attributes and Visual scale characteristics through a fieldwork by the roadside of Pargua highway (Alto Bonito Area) using a scale of attributes adapted from Tveit et al. (2007). Secondly, to measure the type of vegetation through an environmental inventory (phytosociological analysis). Thirdly, to measure the degree of management of the highway considering its maintenance and human intervention.

Wilderness and Naturalness are scarcely observed on the roadside due to a concentrated presence of human interventions such as landfills and overpasses. The visual scale is checked in fieldwork from several scopes. On the southeast side of the road, Las Canchas Area is covered by high trees, houses, and industries which hinder the view of the natural surrounding landscape. On the right side of the road, it presents a clear skyline of Calbuco and Osorno volcanoes. Finally, any management of high quality of the visual scenery of this type of landscape from the route concessionaire is is randomly done. However, the vegetation surface itself has been working out a way to protect the land from erosion and desertification.
\end{abstract}

\section{Keywords:}

Roadside vegetation, Highways, Chile, Naturalness, Visual Scale, Landscape

Submitted: 07 March 2016 / Accepted in revised form: 4 April 2018 / Published: 30 April 2018

*Corresponding author. Email: carolinaojeda@ucsc.cl

(C) The Authors. 2018. Landscape Online. This is an Open Access article distributed under the terms of the Creative Commons Attribution License (http://creativecommons.org/licenses/by/4.0), which permits unrestricted use, distribution, and reproduction in any medium, provided the original work is properly cited. 


\section{Introduction}

\subsection{Background Information}

Highways have become a universal way to transport goods, people, and animals since their massive appearance by the end of the nineteenth century. In the past, the engineering of roads, its traffic related issues, and its management was given the highest importance whereas the ecological issues were neglected by the highway authorities (Spellerberg 2002; Akbar et al. 2003). Nonetheless, roadside greenery aids in reducing the heat island effect and atmospheric pollution. In addition, the small mammal population that lives nearby highways feeds from plants which are contaminated with lead and other noxious atmospheric particles (Quarles III et al. 1974). Over the past two decades, bird watching has been increasingly promoted as a tool to achieve outcomes for conservation and development - particularly in rural areas of low and middle-income countries - through selecting and training local bird watching guides from low-income communities (Biggs et al. 2011; Ulrich 1983). Given that highway verges could be favorable to birds, they may complement the dominant environment within a landscape (Meunier et al. 1999).

Research shows that people prefer scenes with vegetation over scenes with man-made structures (Kaplan et al. 1989). The preference for nature also applies to roadways in which people prefer less developed and more scenic routes (Clay \& Smidt 2004; Ulrich 1983). A 2003 study tested if vegetation along highways could mitigate drivers' anger and frustration. The results showed a higher tolerance to frustration after exposure to videotapes which broadcasted people driving alongside vegetated roadsides (Cackowski \& Nasar 2003). When highways are constructed, the existing natural landscape or the existing developed landscape are rarely conserved, resulting in the loss of valuable natural and historical areas. However, the perception and value of these landscapes differ among people (Jaal \& Abdullah 2012). For example, D. Meinig (1979) carried out an experiment to explore "observer bias" tendencies. The experiment basically dealt with exposing different biases that affect landscape interpretation in a focus group session that considered ten people's perceptions of the identical landscape. The main result is resumed in the phrase: "Any landscape is composed not only of what lies before our eyes but what lies within our heads" (Motloch 2001).

Researchers have theorized that landscape preference increases or decreases in order of importance with the degree of wilderness of the landscape, the presence of well-preserved manmade elements, the percentage of plant covers, the amount of water, the presence of mountains, and the color contrast (Jaal \& Abdullah 2012; Tveit et al. 2007; Arriaza et al. 2004; Clay \& Smidt 2004). A comparison between natural and artificial or manmade landscape can be drawn (Table 1). Parameters for assessing naturalness include indicators that the landscape has developed naturally: natural elements, lines, patterns, and materials; the presence of natural and semi-natural small biotopes and old trees (Van Mansvelt \& Kuiper 1999). Hanyu (2000) assessed naturalness as the cover of trees, flowers and other vegetation in residential scenes. A variety of colors, in this context, has been found to have positive effects on preferences (Hands \& Brown 2002).

Visual scale is a concept strongly emphasized in theories related to visual quality and landscape preferences (Terry 2001). The different approaches can consider the determining visual landscape elements from two different perspectives: one that integrates the intrinsic components of the visual territory and another that relates to the variables that determine the perception of the landscape and its assessment (Fidalgo 2014).

The concept of visual scale addresses the experience of landscape rooms or perceptual units, in other words, their size, shape, diversity and linear features (Kiinkenberg 1994). In this way, the scale is affected by a line of sight and background. Additionally, it is related to the grain size or degree of openness in a given landscape.

The observer plays an important role to define the visual landscape features because it supplies the increasing modern human needs like well-being and happiness (Harari 2017). In this matter, the natural 
Table 1: Naturalness characteristics of landscapes. Adapted from Tveit et al. (2007).

\begin{tabular}{|l|l|}
\hline \multicolumn{2}{|c|}{ NATURALNESS } \\
\hline Concept & Naturalness as closeness to a preconceived natural state. \\
\hline Dimensions & Intactness; wilderness; natural; ecologically robust \\
\hline $\begin{array}{l}\text { Landscape } \\
\text { attributes }\end{array}$ & $\begin{array}{l}\text { Natural feature; structural integrity of vegetation; vegetation/land-cover type; } \\
\text { water; management; patch shape; edge shape. }\end{array}$ \\
\hline $\begin{array}{l}\text { Potential } \\
\text { indicators }\end{array}$ & $\begin{array}{l}\text { Fractal dimension; vegetation intactness; percentage area with permanent } \\
\text { vegetation cover; the presence of water; percentage area water; the presence } \\
\text { of natural feature; lack of management; management intensity (type and } \\
\text { frequency), naturalism index, the degree of wilderness. }\end{array}$ \\
\hline \multicolumn{2}{|c|}{ VISUAL SCALE } \\
\hline Concept & $\begin{array}{l}\text { Visual scale by the perceptual units that reflect the experience of landscape } \\
\text { rooms, visibility, and openness. }\end{array}$ \\
\hline Dimensions & Visibility; openness; grain size. \\
\hline $\begin{array}{l}\text { Landscape } \\
\text { attributes }\end{array}$ & Topography; vegetation; man-made obstacle. \\
\hline $\begin{array}{l}\text { Potential } \\
\text { indicators }\end{array}$ & $\begin{array}{l}\text { Viewshed size; viewshed form; depth of view; the degree of openness; grain } \\
\text { size; the number of obstructing objects. }\end{array}$ \\
\hline
\end{tabular}

balance and the relations between humanity and nature urn out more unbalanced than ever. Thus, the physical and ecological resources that contribute to visual features are the basis of the scenic landscape and important in evaluation and management (Eroglu et al. 2012), restoring some balance to that relationship.

According to the studies of Herzog et al. (2000) and Velarde et al. (2007), the degree of openness is directly related to landscape preferences in natural scenarios: field/forest with a high and low degree of openness induces to a higher tranquility and a lower feeling of danger. Which elements from the view contribute the most to diversity and to what extent spatial patterns of these elements are important, are some of the questions that would benefit from further studies (Ward 2011). The presence of wellpreserved man-made elements, the amount of water and the presence of mountains are taken into account by Arriaza et al. (2004) and Schirpke et al. (2013) in the category of man-made obstacles for visual scale and assessment of scenic beauty landscape.

\subsection{Objectives}

The objective of this research is threefold:

1) Measuring the presence of main Landscape Attributes and Visual Scale characteristics through a checklist

2) Measuring the naturalness of vegetation through an environmental inventory, and

3) Measuring the degree of management of the highway based on human intervention (infrastructure) and maintenance.

\subsection{Study Area}

The study area of this work is a zone of $2 \mathrm{~km}^{2}$ of Pargua Highway (Figure 1) located in Alto Bonito (Long $-73^{\circ} 0^{\prime} 51.2^{\prime \prime}$; Lat. $-41^{\circ} 29^{\prime} 0.2$ ). It is surrounded by an urban boost explained by a clear access to Chiloé Island and Palena province ${ }^{1}$. This highway creates an artificial division among the districts of Puerto Montt, Calbuco, and Maullín.

1 See further information: http://www.concesiones.cl/ proyectos/Paginas/detalleConstruccion.aspx?item=4 (Date: 04.05.2018) 
Until the early 90's, housing projects were predominant in Chile. As years went by, the government was unable to tackle a public infrastructure deficit that reached almost US\$12.5 billion. A legal framework was created to cover this gap and road concessions appeared. In this way, the government transfers to a private partner those projects in which demand is sufficient to support a "user pay" principle (Foreign Investment Committee 2009).

By 2010 Chile has over $2.500 \mathrm{~km}$ of privately operated highways of at least four lanes each. Intercity highways, like Pargua Highway, are a network of infrastructure including roads, junctions, tunnels, overpasses and underpasses, pedestrian walkways, road defenses, entry/exit lanes and crossings for animal and machinery.

In this particular case, the fishing and agro forest industries have increased the flow of heavy trucks on the highway, particularly nearby Calbuco, with the consequent deterioration of the road. This phenomenon has led to an ever-increasing risk of minor and serious accidents such as bumping small cars and running over pedestrians in secondary roads correspondingly. Additionally, a high vulnerability to adverse weather conditions in winter ${ }^{2}$ like fog, frost, and rainfall has been detected.

Considering this scope, plenty of foreign visitors prefer to use Pargua highway to go to Chiloé due to the natural landscape all along the road. Applying the same cost-benefit reasoning, it follows that the natural scenery along the parkway must be financially worthwhile according to Ulrich: "motorists consciously gave up large amounts of time in order to experience the roadsides surrounded by forest or vegetation" (Ulrich 1973). Today it is not the destination itself but the journey that arouses a major interest among travelers. Consequently, the tourists may observe a large number of stalls and services along highways as well as the sight of entire families driving out of the city to enjoy the beauties of the countryside (Felsenhardt 2003).

2 See further information at: http://www.rutadelcanal.cl/ sobre-el-proyecto/ (Date: 04.05.2018).
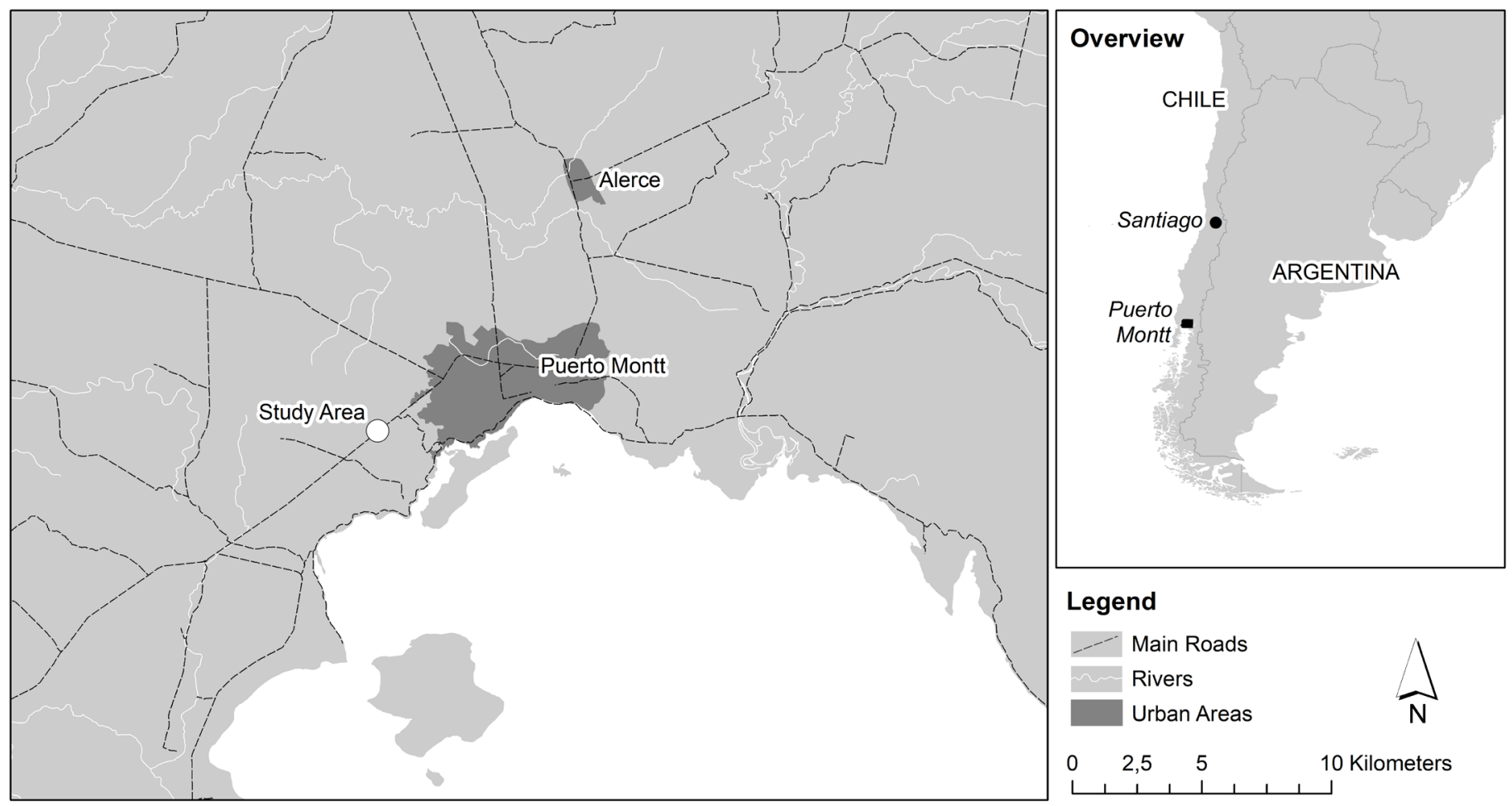

Figure 1: Location of the study area at Pargua Highway, Alto Bonito in Puerto Montt - Chile (Ruta 5 Sur Km 6). 


\section{Methodology}

This is an exploratory study that includes a fieldtrip to the area of study (Pargua Highway Km 6) during January 2016. It is summer in South America, and it coincides with high temperatures and a peak of visitors in the area.

In order to measure the landscape natural attributes and visual scales, a single matrix of indicators is created based on the presence of man-made obstacles (Arriaza et al. 2004), perceptual units (Kiinkenberg 1994), and a comparison between natural and artificial elements (Tveit et al. 2007). Besides, a revision of photographic material, field notes, and observations of the fieldwork are made through expert-based scenic assessment. Each broad light photo is scored according to the scale of measurement shown in Appendix 1. After visiting the field, the photos are reviewed and scored twice to eliminate possible reading errors. The species of flora and fauna found along the roadside were not damaged while conducting this study.

The analysis considered an average observer's height of $1.65 \mathrm{~m}$ which corresponds to the average height that an observer may have on the ground at the highest point of Alto Bonito Area (Las Cabañas Area). The second point of observation was the lowest point in the roadside in Las Canchas area (Fig. 2). The area included in the view shed is $0,3675 \mathrm{~km}^{2}$. Following the method presented by W.E. Dramstad et al. (2006) 15 to 25 photographs were taken in both viewpoints. The aim is to describe the landscape content and variation throughout the area (Puchmann \& Dramstad 2003).

\section{Results}

\section{a) Naturalness}

A checklist was created to measure the naturalness characteristics based on Tveit et al. (2007) using the categories and the variables observed in the fieldtrip as well as the photographs. The matrix of values is presented in Appendix 1. This highway has plenty of colorful flowers corresponding to either native or introduced flora like Cartucho (Digitalis purpurea nevit), Dandelion (Taraxacum), Nalca (Gunnera tinctoria), Helecho Costilla De Vaca (Blechnum cordatum), Fern (Dicksonia squarrosa), Chilco

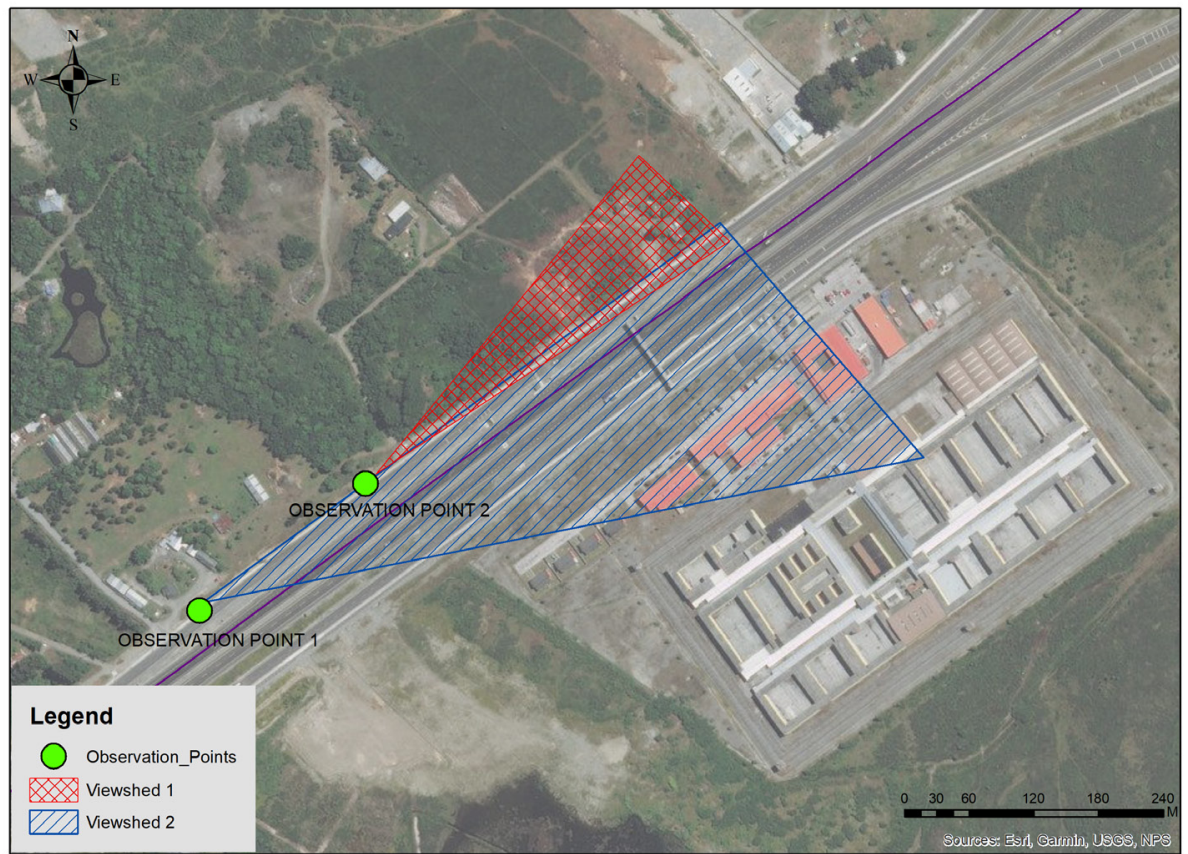

Figure 2: Map showing the place pictures were taken at Route 5 South $\mathrm{Km} 6$. Illustrating trees and visual obstacles on the left side of the road and the man-made constructions. The triangles show the visual shed and openness degree. The area included in the visual basin is $0,3675 \mathrm{~km}^{2}$. 


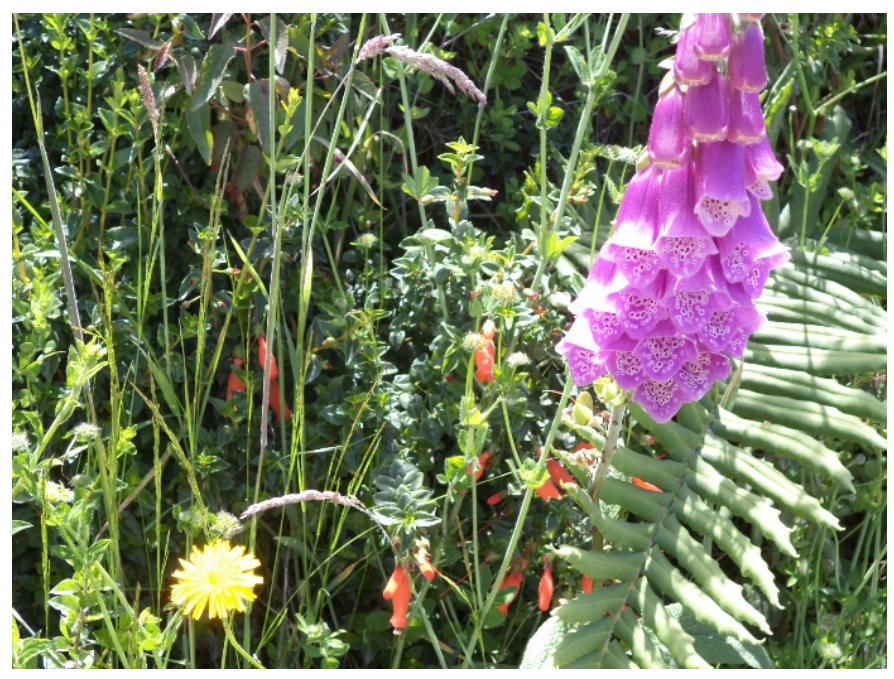

Figure 3: Colorful flowers observed at the roadside.

(Fuchsia magellanica), Chamomile (Matricaria chamomilla), Alexandrine Clover (Trifolium alexandrinum), Persian Clover (Trifolium pratense), Cardillo (Acaena alpine), White Clover (Trifolium repens). All of these species grow spontaneously in what is left of natural environment along the road. Nevertheless, trash is observed in large areas (Fig.2).

Colors and textures were measured in fieldwork and scored with high values (Appendix 1). The number of colors scored three or more in vegetation, horizon and a clear blue sky, adding a pleasant view without pollution currently found in cities. The presence of internal contrast is scored 2, which is a rather high value, essentially for the clear contrast between colors of man-made objects (grey-white) and vegetation/ sky (green, yellow, pink, blue, white). The texture is medium (scored 2) according to photographic observation of landscape elements (Gibson 1979), the man-made elements were classified as smooth (scored 1 ) because the materials were made of concrete, plastic and steel-, and the natural elements are classified as rough because of the composition of non-homogeneous natural textures: grass, trees, grains of soil, bushes, rocks, etc. Nevertheless, it is well documented that when increasing distance, long views affect the visual properties and colors of the objects and lightness contrast (Shang \& Bishop 2000; Altman \& Wohlwi 2013).

Observed empirically, the degree of intactness in the vegetation (Tveit et al. 2007) is scored as 2 during the fieldwork because of the presence of assorted vegetation. That heterogeneity is based on the combination of bushes and trees. The degree of wilderness has a score of 0 , due to the presence of houses, roads, vacant lots, fence lines, shorelines, and the edges of public and private rights of roads (e.g. utility corridors and roadside strips). The human interruption is negatively observed with the presence of trash at the roadside, the noise of trucks and cars, the power lines, the pollution from the automobiles, and abandoned domestic animals like dogs (Fig 4). Despite that, nearby trees are the habitat for some endemic and exotic birds like bandurrias (Theristicus caudatus), jote de cabezacolorada (Cathartes aura), sparrows (Passeridae), treiles (Vallenus chilensis), Chilean swallows (Tachycineta meyeni) and tiuques (Milvago chimango). All of them which were observed and listened to during the fieldwork.

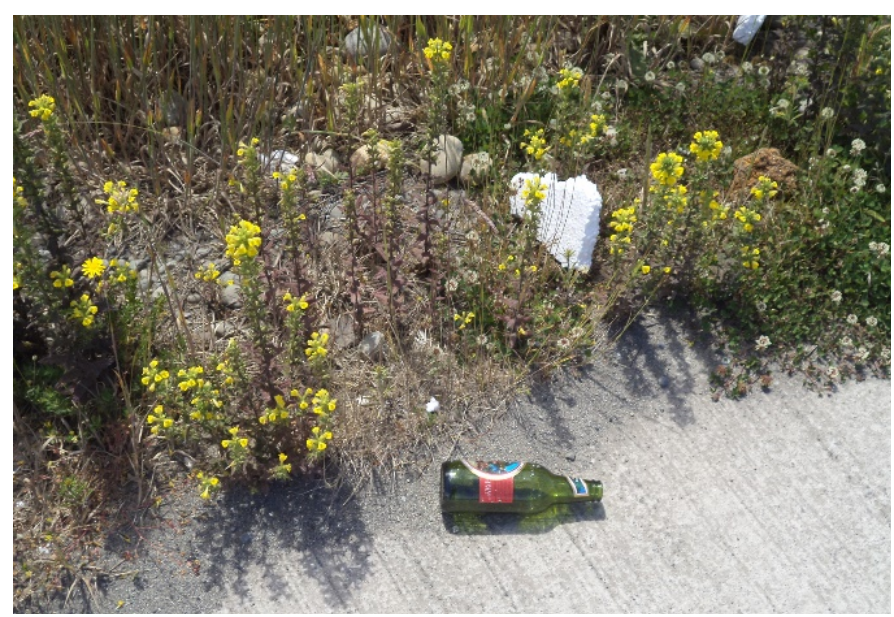

Figure 4: Trash found in the roadside study area.

Ecological robustness is the ability of an ecosystem to maintain its normal patterns of nutrient cycling and biomass production after being subjected to damage caused by an ecological disturbance. Undoubtedly because of how they are perceived, plants are the elements that mostly contribute to the landscape in units which have syntaxonomical associations (Muñoz-Pedreros \& Larraín 2002). This does not mean that an imperceptible component of a given ecosystem has no role in a landscape, even if it is out of sight. Most insects are not noticeable in a patch (Fig. 5), but contribute to its structure, for example without Hymenoptera diptera and many entomophiles pollinating the plants would not exist (González 1981). 


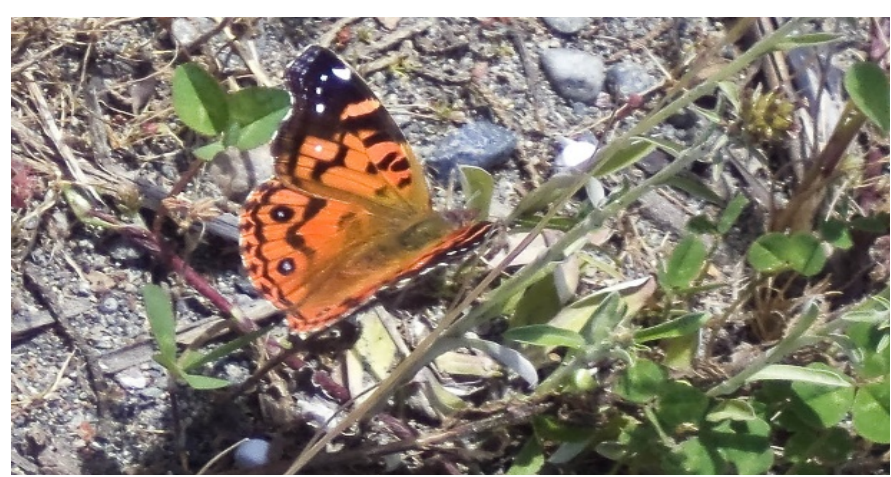

Figure 5: Ecosystem interactions between a butterfly and a patch of clover.

The natural features observed in the patch shape reveal that predominant elements are man-made, all of them created in cement forming gross lines. The observed structural integrity of vegetation is relatively pure, endemic and preserve its intactness after the construction of the roadside, spreading by itself in random patterns.

The Naturalism index for each landscape uses a score ranging from 1 to 5 (Zube 1987). Naturalism refers to the extent to which a land unit resembles its natural state. The converse might be a measure of the degree of urbanism or man's intrusion into the landscape. The assumption is that the higher the naturalism is, the higher is the scenic quality. Through this study, the naturalism index is subjectively assigned according to the number of artificial objects found across the land. At the time of this study, there were 96 man-made objects in the surroundings of the highway, including buildings like a prison and a juvenile prison, houses, power lines, trash, etc. Although the total area of the study region is near $0.37 \mathrm{~km}^{2}$, it should be noted that the presence of trees, hills, and road slopes reduce the effective visual area.

Thus, the naturalism index is scored as 1 (low). It is recognized, however, that a well located and sensitively designed development can enhance the scenic quality of an area (Unwin 1975), and does not necessarily represent a degradation e.g. research shows that people generally prefer park scenes to scenes of raw wilderness (Kaplan \& Kaplan 1989). Still, the objects found through the study area lack of beauty or urban planning and responds in a major way to functional and transporting purposes.
During the fieldwork, there was no presence of superficial water (0\%) observed. Patch and edge shape visual quality are often associated with the degree of the wilderness of the landscape (Leopold 1925; Arriaza et al. 2004). This degree is calculated based on direct observation of the presence of houses, roads, crops without man-made elements and wild vegetation. These last elements are more valuable, however, we observed primarily man-made elements rather than wild vegetation, obtaining a degree of the wilderness of 0 .

The management activity is defined as a: "surfacedisturbing activity undertaken on the landscape for the purpose of harvesting, traversing, transporting, protecting, changing, replenishing, or otherwise using resources" (Bureau of Land Management 1984). The management of highways in Chile is carried out by private concessioners which have no department in charge of roadside vegetation or fauna such as pruning of trees, cleaning of canals and footbridges, and maintenance of road signagerailings. According to the web page of concessioners, it is highly orientated to preserves the pedestrian and driver security on the highway ${ }^{3}$. The Ministry of Public Works (MOP, by its initials in Spanish) does not have a clear policy about highway roadside management regarding vegetation or landscapes.

The only regulations apply to the design of some routes with touristic interest or biodiversity conservancy features which are usually surrounded by water elements -Visual Resource Management (VRM)-.In this case the roadside was not properly managed by the concessioner at the fieldwork, however, it is worth mentioning that a year later a clearing of canals and footbridges and the maintenance of road signage-railings was observed.

\section{b) Visual Scale}

Landscape unveils itself as an independent, objective phenomenon; something like the image in a vertical

3 See detailed information: http://www.rutadelcanal. cl/proyecto-ruta-del-canal/obras-del-proyecto/ (Date: 04.05.2018) 
air photograph which is seen very differently by the observer as a series of oblique views is unique to the viewer and viewpoint (Unwin 1975; Duhl et al. 2012).

Openness is not measured at this stage but pictures are chosen subjectively based on perceived openness. An open landscape is defined as a landscape with low vegetation allowing a clear view, as opposed to tall vegetation which obscures the view (Dramstad et al. 2006). Viewshed size is measured by the values on a vertical angle ranging from $90^{\circ}$ (looking straight up) to $-90^{\circ}$ (looking straight down). In this way, a clear view from the highest point of the route at $\mathrm{km} 6$ is obtained. A pedestrian overpass is the only visible obstacle in front of the observer in viewpoint 2. The south eastside of the road (Las Canchas Area) is covered by high trees, houses and industrial sites, so the viewshed is $0 \%$ (viewpoint 2 ).

Man-made obstructing objects were observed such as a pedestrian Passover, containment barrier, pylons, lampposts, houses, a prison, a juvenile prison, and a dividing grid (Fig. 6). These elements are parts of the urban sprawl that affects Puerto Montt and its rural areas. In summary, these man-made elements accumulate mainly because the city does not have enough space to absorb them. Therefore, the highway loses its purpose of connecting productive areas and becoming a spine for a new suburban area.
According to Escribano et al. (1991) the visual scale of the landscape includes:

(a) the intrinsic visual quality of the landscape in which the observer is located,

(b) the visual quality of the immediate environment at a distance exceeding $(700 \mathrm{~m})$, and

(c) the quality of scenic background, understood as the set of the visual base of each landscape.

In this study, the emphasisis given to all the above elements, since the intrinsic value is defined depending on the observer, the study area, vegetation cover, and horizon line (Gandy \& Meitner 2007; Clay $\&$ Smidt 2004). Despite the presence of man-made objects, the visual scale is well preserved especially on sunny days when the horizon line and the roadside seem to fuse and form a continuum, thus the score of 1 . The Calbuco and Osorno volcanoes can be seen even if when they are located geographically far away from viewpoints1 and 2. Also, the populated city of Puerto Montt is partly seen. Consequently, the horizon indicator and the focal view are scored with 2 and 1 value, respectively.

According to the information provided by the highway management, the visibility can fall to nearly zero meters during winter months (between May and July) due to the formation of a dense fog, in consequence causing traffic problems and car accidents.

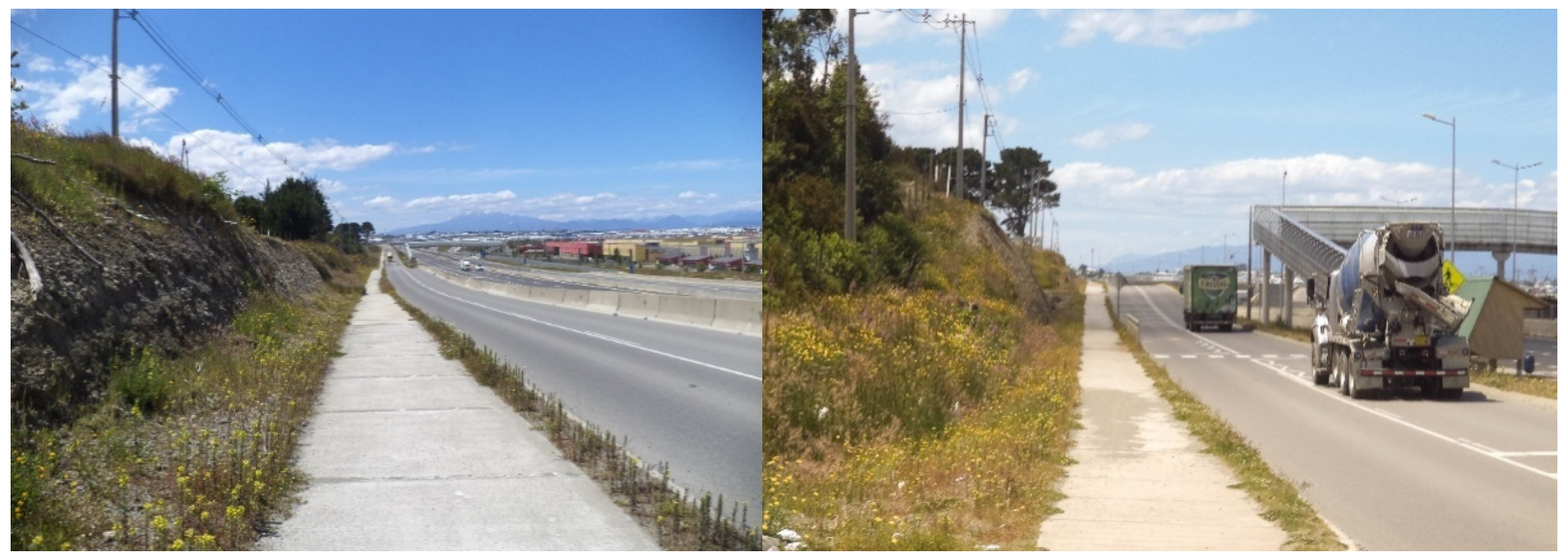

Viewpoint 1

Viewpoint 2

Figure 6: of landscape and man-made obstructing objects from viewpoint 1-2. 


\section{Conclusions}

In the case of scenic highway initiatives, the action framework extends beyond the impact of singular elements such as physiographic features and tree masses. Cultural additions (land use, historical structures), transportation concerns (motivations for travel, travel speed, the frequency of use), and transitional relationships (environmental shifts, elevation changes) somehow impact the viewer's experience. Furthermore, the linearity of a corridor reinforces the importance of spatial arrangement and visual sequencing.

It appears to be that improving the management of roadside vegetation and its aesthetic value is a complicated activity due to several opposing interests. The studies performed by Akbar et al. (2003) investigated these complexities and proved that highway users showed a positive attitude towards establishing a variety of vegetation types instead of a uniform seed mixture. Despite this, the management of most chilean highways are not legally forced to support higher investments on the improvement of the scenic beauty of roadside vegetation (Zalina \& Jamalunlaili 2012). This paradox calls for the introduction of cost-effective methods for re-vegetation and supervision of roadside verges. These findings address simultaneously to the engineering objectives, concessionaire's earnings and commuters demands for scenic and aesthetic quality.

Following the field visit to the roadside of Pargua Highway (Alto Bonito Area) a checklist was compiled with the main Landscape Attributes: Natural feature, Structural integrity of vegetation, Vegetation/ land-cover type, Water management, Color and textures, Patch shape, Edge shape, and Visual scale characteristics: Landscape attributes, Topography, Horizon, Degree of openness in vegetation, Manmade obstacles.

Although management of a high-quality landscape visual scenery from the route concessionaire is randomly done, nature itself has been working on maintaining a high degree of vegetation intactness (shrubs and trees) to cover the land and to protect the soil from erosion and desertification. The human disruption evidence negative aspects such as the presence of trash along the road and noise pollution from traffic. In spite of this fact, local birds and colorful flowers were found in the same area. In order to reduce high pitch noises and preserve the usual tranquility of that viewpoint, a noise-canceling policy should be applied.

It is also urgent to promote the protection of trees and vegetation, especially for birdwatching. In addition, planting trees with overarching canopies can help small mammals, birds, and insects to safely cross the roads and highways, e.g. the urban Echolink in Rua Gonçalo de Carvalho in Porto Alegre, Brazil (Secretariat of the Convention on Biological Diversity 2012).

The concept of visual scale deals with the experience of landscape rooms or perceptual units in terms of size, shape, diversity and linear features. During the fieldwork, Calbuco and Osorno volcanoes and even the populated city of Puerto Montt were clearly viewed, adding openness and a highly scored visual scale. Despite the presence of man-made elements proper of a highway (pedestrian overpasses, containment barrier suing, pylons, lamppost, houses, a prison, and road defenses), the viewshed is clear from both viewpoints.

Researchers have discovered that naturalness of some road sections of highways that include native and introduced elements like tree lines and vegetation patterns could reduce stress and anger among drivers (Cackowski \& Nasar 2003). The management of roadside highways and the preservation of visual scales could improve social and economic aspects as long as the highway stakeholders create a tourist viewpoint. In this case, a large number of tourists would go sightseeing alongside the highway using the bike lane to get to Chiloé Island. 


\section{Acknowledgments}

The author wishes to express her deep gratitude to Dr. Roberto E. Navarro and EFL Teacher Karen Ojeda. Also, the anonymous reviewers and the Editorial Team for their constructive comments and suggestions in regards to improving the quality of English language.

\section{References}

Akbar, K.F.; Hale, W.H.G. \& Headley, A.D. 2003. Assessment of scenic beauty of the roadside vegetation in northern England. Landscape and Urban Planning 63, 139-144. DOI: 10.1016/ S0169-2046(02)00185-8

Altman, I. \& Wohlwi, J.F. 2013. Human Behavior and Environment: Advances in Theory and Research. Springer, New York.

Arriaza, M.; Cañas-Ortega, J. F.; Cañas-Madueno, J. A. \& Ruiz-Avilés, P. 2004. Assessing the visual quality of rural landscapes. Landscape and urban planning 69(1), 115-125. DOI: 10.1016/j. landurbplan.2003.10.029

Biggs, D.; Turpie, J.; Fabricius, C. \& Spenceley, A. 2011. The value of avitourism for conservation and job creation-An analysis from South Africa. Conservat Soc 9:80-90. DOI: 10.4103/0972-4923.79198

Bureau of Land Management 1984. Manual 8400 Visual Resource Management. Department of the Interior, Washington, D.C.

Cackowski, J.M. \& Nasar, J.L. 2003. The Restorative Effects of Roadside Vegetation. Implications for Automobile Driver Anger and Frustration. Environment and Behavior 35 (6), 736-75. DOI: 10.1177/0013916503256267
Clay, G.R. \& Smidt, R. K. 2004. Assessing the validity and reliability of descriptor variables used in scenic highway analysis. Landscape and Urban Planning 66, 239-255. DOI:10.1016/S01692046(03)00114-2

Dramstad W.E.; Sundli Tveit M.; Fjellstad, W.J. \& Fry, G.L.A. 2006. Relationships between visual landscape preferences and map-based indicators of landscape structure. Landscape and Urban Planning 78 465-474. DOI:10.1016/j. landurbplan.2005.12.006

Duhl T.R.; Guenther, A. \& Helmig, D. 2012. Estimating urban vegetation cover fraction using Google Earth $^{\circledR}$ images. Journal of Land Use Science 7(3), 311-329. DOI: 10.1080/1747423X.2011.587207

Eroglu, E.; Müderrisoglu, H. \& Akıncı Kesim, G. 2012. The effect of seasonal change of plants compositions on visual perception. Journal of Environmental Engineering and Landscape Management 20(3), 196-205. DOI:10.3846/1648 6897.2011.646007

Escribano, M.M.; De Frutos, M.; Iglesias, E.; Mataix, C. \& Torrecilla, I. 1991. El Paisaje. Ministerio de Obras Públicas y Transportes, Madrid. 117 pp.

Felsenhardt, C. 2003. Nuevas geometrías en viejos paisajes. $A R Q$ 54, 10-14. https://scielo.conicyt.cl/ pdf/arq/n54/art04.pdf (Date: 04.05.2018)

Fidalgo, P. 2014. Aportaciones para la definición de elementos visuales determinantes del paisaje. Cuadernos de Investigación Urbanística 92, 5-83.

Foreign Investment Committee 2009. Chile, opportunities in infrastructure (2009-2010). Ministry of Public Works, Santiago. 80 pp. https://www.mop.cl/Documents/chile\%20 opportunities\%20in\%20infrastructure.pdf (Date: 04.05.2018) 
Gandy, R. \& Meitner, M.J. 2007. The effects of an advanced traveler information system on scenic beauty ratings and the enjoyment of a recreational drive. Landscape and Urban Planning 82, 85-93. DOI:10.1016/j.landurbplan.2007.01.018

Gibson, J. J. 1979. The Ecological Approach to Visual Perception. Houghton Mifflin, Boston. 346 pp.

González, F. 1981. Ecología y paisaje. Editorial H. Blume, Spain. 256 pp.

Hands, D. E. \& Brown, R. D. 2002. Enhancing visual preference of ecological rehabilitation sites. Landscape and Urban Planning 58, 57 - 70. DOI: 10.1016/S0169-2046(01)00240-7

Hanyu, K. 2000. Visual properties and affective appraisals in residential areas in daylight. Journal of Environmental Psychology 20, 273 - 284. DOI: 10.1016/S0169-2046(01)00240-7

Harari, Y. N. \& Perkins, D. 2017. Sapiens: A brief history of humankind. Harper Collins, New York. $486 \mathrm{pp}$.

Herzog, T.R. \& Chernick, K.K. 2000. Tranquility and danger in urban and natural settings. Journal of Environmental Psychology 20, 29-39. DOI: 10.1006/jevp.1999.0151

Jaal, Z. \& Abdullah, J. 2012. User's Preferences of Highway Landscapes in Malaysia: A Review and Analysis of the Literature. Procedia - Social and Behavioral Sciences 36, 265-272. DOI: 10.1016/j. sbspro.2012.03.029

Kaplan, R. \& Kaplan, S. 1989. The experience of nature: A psychological perspective. Cambridge University Press, USA.

Kaplan, R.; Kaplan, S. \& Brown, T. 1989. Environmental preference's comparison of four domains of predictors. Environment and Behavior 21, 509530. DOI: 10.1177/0013916589215001
Kiinkenberg, B. 1994. A Review of Methods Used to Determine the Fractal Dimension of Linear Features. Mathematical Geology 26 (1), 23-46. http://ibis.geog.ubc.ca/ brian/ publications/review_of_methods_fractals.pdf (Date: 11.01.2016)

Leopold, A. 1925. Wilderness as a Form of Land Use. The Journal of Land \& Public Utility Economics 1(4), 398-404. DOI: 10.2307/3138647

Meunier, Francis D.; Verheyden, C. \& Jouventin, P. 1999. Bird communities of highway verge: Influence of adjacent habitat and roadside management. Acta Oecologica 20, 1-13. DOI: 10.1016/S1146-609X(99)80010-1

Meinig D (ed.) 1979. The Interpretation of Ordinary Landscapes. Oxford University Press, New York

Motloch, L.M. 2001. Introduction to Landscape Design. John Wiley \& Sons, Inc., New York.

Ministerio de Obras Públicas (MOP). Concesiones en Chile. http://www.concesiones.cl/proyectos/ Paginas/detalleConstruccion.aspx?item $=4$ (Date: 04.05.2018)

Muñoz-Pedreros, A. \& Larraín, A. 2002. The impact of forestry, agriculture, and cattle grazing activities on the quality of landscape in a transect of southern Chile. Revista Chilena de Historia Natural 75(4), 673-689. DOI: 10.4067/S0716$078 \times 2002000400004$

Puchmann, O. \& Dramstad, W.E. 2003. Documenting landscape change through fixed angle photography. In: W.E. Dramstad \& Sogge, C. (eds.): Agricultural Impacts on Landscapes: Developing Indicators for Policy Analysis. NIJOS/Landscape Europe: London.

Quarles III, H. D.; Hanawalt, R. B. \& Odum, W.E. 1974. Lead in Small Mammals, Plants, and Soil at Varying Distances from a Highway. Journal of Applied Ecology 11(3), 937-949. DOI: 10.2307/2401755 
Ruta del Canal Concessionaire. http://www. rutadelcanal.cl/sobre-el-proyecto/ (Date: 04.05.2018)

Secretariat of the Convention on Biological Diversity (2012). Cities and Biodiversity Outlook. Action and Policy. Montreal, Canada. http://www.cbd. int/en/subnational/partners-and-initiatives/cbo (Date: 04.05.2018)

Shang, H., \& Bishop, I. D. 2000. Visual thresholds for detection, recognition and visual impact in landscape settings. Journal of environmental psychology 20(2), 125-140. DOI:10.1006/ jevp.1999.0153

Schirpke, U.; Hölzler, S.; Leitinger, G.; Bacher, M.; Tappeiner, U. \& Tasser, E. 2013. Can We Model the Scenic Beauty of an Alpine Landscape? Sustainability 5(3), 1080-1094 DOI: 10.3390/ su5031080

Spellerberg, I.A.N. 1998. Ecological effects of roads and traffic: a literature review. Global Ecology and Biogeography, 7(5), pp.317-333. DOI: 10.1046/j.1466-822x.1998.00308.x

Terry, C.D. 2001. Whither scenic beauty? Visual landscape quality assessment in the 21st century. Landscape and Urban Planning, 54(1-4), 267281. DOI: 10.1016/S0169-2046(01)00141-4

Tveit, M; Ode, Å. \& Fry, G. 2007. Key concepts in a framework for analysing visual landscape character, Landscape Research, 31:3, 229-255, DOI: 10.1080/01426390600783269

Ulrich, R.S. 1983. Aesthetic and affective response to natural environment. In: I. Altman \&. Wohlwill, J.F (eds.): Behavior and the Natural Environment. Plenum Press; New York.

Ulrich, R.S. 1973. The scenery and the Shopping Trip: The Roadside Environment as a Factor in Route Choice. University of Michigan, Ann Arbor.
Unwin, K. 1975. The Relationship between Observer and Landscape in Landscape Evaluation. Transactions of the Institute of British Geographers 66, 130-134. DOI: 10.2307/621627

Van Mansvelt, J. D. \& Kuiper, J. 1999. Criteria for the human realm: psychology and physiognomy and cultural heritage. In: J. D. van Mansvelt \& van der Lubbe, M. J. (eds): Checklist for Sustainable Landscape Management. Elsevier Science, Amsterdam.

Velarde, M.D.; Fry, G. \& Tveit, M. 2007. Health effects of viewing landscapes - Landscape types in environmental psychology. Urban Forestry \& Urban Greening 6(4), 199-212. DOI: 10.1016/j. ufug.2007.07.001

Ward, C. 2011. Linking landscape and health: The recurring theme. Landscape and Urban Planning 99(3-4), 187-195. DOI:10.1016/j. landurbplan.2010.10.006

Zalina J. \& Jamalunlaili, A. 2012. Users' Preferences of Highway Landscapes in Malaysia: A Review and Analysis of the Literature. Procedia - Social and Behavioral Sciences 36, 265-272. DOI: 10.1016/j. sbspro.2012.03.029

Zube, E. 1987. Perceived land use patterns and landscape values. Landscape Ecology 1, 37-45. DOI: 10.1007/BF02275264 